\title{
Competition and performance : the different roles of labor and capital
}

Citation for published version (APA):

Mohnen, P., \& ten Raa, T. (2003). Competition and performance : the different roles of labor and capital. UNU-MERIT, Maastricht Economic and Social Research and Training Centre on Innovation and Technology. MERIT-Infonomics Research Memorandum Series No. 031 https://doi.org/10.26481/umamer.2003031

Document status and date:

Published: 01/01/2003

DOI:

10.26481/umamer.2003031

Document Version:

Publisher's PDF, also known as Version of record

\section{Please check the document version of this publication:}

- A submitted manuscript is the version of the article upon submission and before peer-review. There can be important differences between the submitted version and the official published version of record.

People interested in the research are advised to contact the author for the final version of the publication, or visit the DOI to the publisher's website.

- The final author version and the galley proof are versions of the publication after peer review.

- The final published version features the final layout of the paper including the volume, issue and page numbers.

Link to publication

\footnotetext{
General rights rights.

- You may freely distribute the URL identifying the publication in the public portal. please follow below link for the End User Agreement:

www.umlib.nl/taverne-license

Take down policy

If you believe that this document breaches copyright please contact us at:

repository@maastrichtuniversity.nl

providing details and we will investigate your claim.
}

Copyright and moral rights for the publications made accessible in the public portal are retained by the authors and/or other copyright owners and it is a condition of accessing publications that users recognise and abide by the legal requirements associated with these

- Users may download and print one copy of any publication from the public portal for the purpose of private study or research.

- You may not further distribute the material or use it for any profit-making activity or commercial gain

If the publication is distributed under the terms of Article $25 \mathrm{fa}$ of the Dutch Copyright Act, indicated by the "Taverne" license above, 


\section{MERIT-Infonomics Research Memorandum series}

Competition and Performance:

The Different Roles of Capital and Labor

Pierre Mohnen \& Thijs ten Raa

2003-031
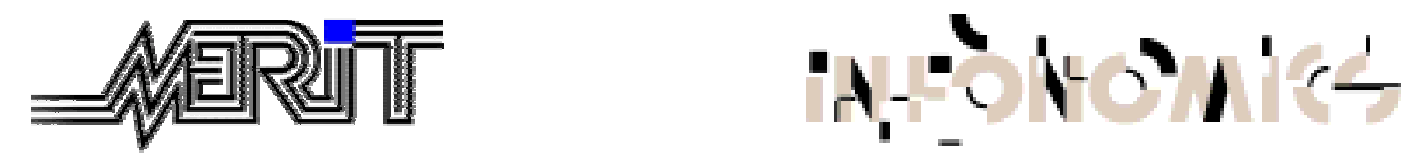

MERIT - Maastricht Economic Research

International Institute of Infonomics

Institute on Innovation and Technology

PO Box 616

6200 MD Maastricht

The Netherlands

T: +31433883875

$F:+31433884905$

c/o Maastricht University

PO Box 616

6200 MD Maastricht

The Netherlands

$\mathrm{T}:+31433883875$

$F:+31453884905$

http://www.merit.unimaas.nl

e-mail:secr-merit@merit.unimaas.nl

http://www.infonomics.nl e-mail: secr@infonomics.nl 


\title{
Competition and Performance:
}

\section{The Different Roles of Capital and Labor}

\author{
Pierre Mohnen \\ University of Maastricht and MERIT \\ p.mohnen@merit.unimaas.nl \\ Thijs ten Raa \\ Tilburg University \\ tenRaa@UvT.nl
}

November, 2003

\begin{abstract}
Neoclassical economists argue that competition promotes efficiency. They consider technology as given though. In the long run technological progress is an important determinant of the level of welfare and Schumpeter argued that monopoly rents help entrepreneurs to capture the gains of $R \& D$ and hence to invest in it. We investigate the overall effect of competition on performance. Performance is measured by TFP-growth. As a negative measure of competition we use rent. Rent is defined as the excess factor rewards over and above their perfectly competitive values (marginal productivities). Input-output analysis enables us to calculate rent for the Canadian sectors over a thirty-year period and to decompose it in its capital and labor components. In line with the literature we find that rent has no significant influence on productivity. We find an interesting result however: the components influence performance in opposite directions. Capital rent has a positive role and labor rent a negative one. The neoclassical economists and Schumpeter seem both right, but the mechanisms differ. The use of rent as a source of funding for R\&D applies to capital and the argument that rent yields slack pertains to labor.
\end{abstract}

Keywords: competition, rent, TFP, Schumpeter hypothesis

JEL codes: L16, O41, C67 


\section{Introduction}

Is competition good for performance? Yes, say neoclassical economists, arguing that it eliminates slack and hence promotes static efficiency. No, say Schumpeter and others, pointing out that monopoly rents induce entrepreneurs to invest in R\&D and thus promote dynamic efficiency. The mechanisms alluded to are quite different and the overall effect of competition becomes an empirical issue. Nickell (1996) finds some support for the view that competition improves performance, but the evidence is not overwhelming. Aghion et al. (2001, 2002) and Boone (2001) argue that the relationship between competition and innovation is non-monotonic. Griffith (2001) finds that product market competition improves performance in principal-agent type firms. We will review the argument in some detail and then pitch our approach.

If a market is more competitive, the stakes of sweeping it by winning an innovation contest are greater, as the scope is wider. On a product-by-product basis, however, margins are lower in a more competitive market. Aghion et al. (2001) combine the two countervailing effects in a single model, where industries are duopolies engaged in price (Bertrand) competition. 'Competition' is measured by the elasticity of substitution between the duopolists' products. A higher degree of substitutability boosts the reward to an innovation winner among leveled firms (the neoclassical effect), but reduces the (marginal) reward to non-leveled firms (the Schumpeterian effect). A level field will become less leveled and the new equilibrium is less congenial for innovation: followers face low rents to gain when demand is more 
elastic, while leaders do not distance themselves further as technological knowledge is assumed to spill over anyway after a single period. Industries become less leveled and the rent dissipation effect overtakes the contest effect. Competition and innovation have an inverted $U$ relationship as a result. In a Hotelling-style example of three vendors Boone (2001) finds a U relationship and notes that "basically anything can happen," but Aghion et al. (2002) find empirical support for the inverted U relationship between competition and innovation.

Since Aghion et al. $(2001,2002)$ measure competition by means of the elasticity of substitution, both the neoclassical and the Schumpeterian effects are channelled through the product markets. This is also the market studied by Griffith (2001), who suggests, however, that agency costs play a role in the scope for performance. We want to analyze the role of factor markets. Do not neoclassical economists argue that competition is good because it keeps managers sharp? And does not Schumpeter argue that monopoly profits are good because they fund R\&D? Labor and capital may play conflicting roles in terms of the relationship between competition and performance. This conflict may explain why there is no simple relationship between the two.

Rather than relating rents to elasticities of demand in a neoclassical model of price competition, we decompose rents into factor components in a classical input-output framework and investigate if the opposing effects of competition operate through different markets. A natural thought seems to be that competition in the labor market 
may be good, but competition in the capital market may be bad, both in terms of performance. In other words, neoclassical and Schumpeterian economists may both be right, but rather than combining the opposing effects in some nonlinear relationship, we point to different factor markets. The potential policy conclusions would be vastly different. The aforementioned literature may suggest an optimal level of product market competition at best. We say at best, because competition is modeled as a shift in consumers' preferences (more substitutability) and firms are assumed to (Bertrand) price compete throughout. In this paper, however, departures from competition are modeled directly as rents and factor markets are targeted.

What do we mean by competition and performance? The measurement of performance is relatively straightforward. Solow (1957) has demonstrated for perfectly competitive economies that the shift of the production possibility frontier, which is the ultimate determinant of the standard of living, is measured by total factor productivity growth (TFP). TFP is also the relevant measure for the standard of living in non- or less competitive economies, where it measures not only the shift of the frontier, but also the change in efficiency (Nishimizu and Page, 1972). In short, we let performance be measured by TFP.

The measurement of competition is trickier. The industrial organization literature provides a number of indices. Perhaps concentration indices are the most popular ones, but we will not employ them. We believe that industries with a low number of firms may well be competitive. In the tradition of Lerner (1934) we measure market 
power more directly by the extent that price has been raised over cost, i.e. by rent. Indeed, Nickell (1996) finds that rent is the most important determinant in the assessment of the influence of competition on performance, but rent is hard to measure. Nickell takes the difference between the rates of return on company capital and treasury bonds and admits this merely measures capital rent, and even as such is only a rough proxy; neoclassical economists point out that competition stamps out labor rent.

In the spirit of Nickell we take rent as the (negative) measure of competition and define it by the difference between actual and perfectly competitive rewards. Actual rewards are given by value-added and perfectly competitive rewards by factor costs at shadow prices. To determine the latter we need a general equilibrium model, which may have been the main obstacle in assessing the role of competition in the performance of an economy. We do so by analyzing Canadian input-output data over the period 1962-1991. Rent and TFP are determined at a level of aggregation that is more macro- than micro-economic.

Section 2 presents the model we employ to determine competitive valuations. Then, in section 3, we define rent and impute it to capital and labor. Section 4 investigates the relationship between competition and performance (as measured by rent and TFP, respectively). 


\section{The productivity model}

Both competition and performance are related to productivity. For performance the connection to productivity is straightforward, as it is measured by TFP, the growth of (total factor) productivity. The connection between competition and rent is slightly more indirect. Competition is (negatively) measured by rent. Rent is the difference between actual and perfectly competitive rewards, where the latter are essentially marginal productivities.

The standard approach to productivity is neoclassical TFP analysis, where output and input components are combined into indices using value shares as weights. The acceptance of value shares at face value is equivalent to taking factor rewards for granted and this procedure has been justified for perfectly competitive economies (Solow 1957 and Jorgenson and Griliches 1967). We, however, are interested in the difference between observed and competitive rewards, and, therefore, cannot apply the standard procedure, but must derive productivities from the real input and output data of the economy.

The model is input-output in spirit, but we admit different numbers of industries and of commodities, as in activity analysis. Industries transform factor inputs and intermediate inputs into outputs and the net output commodity vector feeds domestic final demand and net exports. The marginal productivities of the factor inputs are the shadow prices associated with the factor constraints of the program that maximizes 
welfare. Now if we assume that producers use Leontief technologies and end users of the commodities have Leontief preferences, then the formulas governing these shadow prices are perfectly consistent with neoclassical growth accounting and, moreover, capture the efficiency change effect of frontier analysis; see ten Raa and Mohnen (2000).

The model maximizes the level of domestic final demand, given its commodity proportions and subject to material balances, factor constraints, and balance of payments.

$$
\begin{aligned}
\max _{s, c, g} e^{\mathrm{T}} f c & \text { subject to } \\
\left(V^{T}-U\right) s & \geq f c+J g=: F \\
K s & \leq M \\
L s & \leq N \\
-\pi g & \leq-\pi g^{t}=: D \\
s & \geq 0
\end{aligned}
$$

The variables $(s, c, g)$ and parameters (all other) are the following [with dimensions in brackets]

$s \quad$ activity vector [\# of industries]

c level of domestic final demand [scalar]

$g \quad$ vector of net exports [\# of tradable commodities]

e unit vector of all components one 
$\mathrm{T} \quad$ transposition symbol

$f \quad$ domestic final demand [\# of commodities]

$V \quad$ make table [\# of industries by \# of commodities]

$U \quad$ use table [\# of commodities by \# of industries]

$J \quad 0-1$ matrix placing tradable [\# of commodities by \# of tradables]

F potential final demand [\# of commodities]

$K \quad$ capital stock matrix [\# of capital types by \# of industries]

M capital endowment [\# of capital types]

L labor employment row vector [\# of industries]

$N \quad$ labor force [scalar]

$\pi \quad$ U.S. relative price row vector [\# of tradable]

$g^{t} \quad$ vector of net exports observed at time $t$ [\# of tradable]

D observed trade deficit [scalar]

We denote the shadow prices associated to the constraints of program (1) by $p$ (a row vector of commodity prices), $r$ (a row vector of capital productivities), $w$ (a scalar for labor productivity), $\varepsilon$ (a scalar for the purchasing power parity), and $\sigma$ (a row vector of slacks for the sectors). Then the dual constraints read

$$
\begin{aligned}
p\left(V^{T}-U\right) & =r K+w L-\sigma \\
p f & =e^{T} f \\
p J & =\varepsilon \pi
\end{aligned}
$$


The first dual constraint equates value added to factor costs for active industries (which have zero slack according to the theory of linear programming), all at shadow prices. The second dual constraint normalizes the level of commodity prices by the multiplicative constant we entered in the objective function of (1). The third dual constraint aligns the prices of the tradable commodities with the terms of trade.

Capital and labor productivity are given by shadow prices $r$ and $w$ (and foreign debt productivity by $\varepsilon$ ). In total, frontier productivity growth amounts

$$
F P=(\dot{r} M+\dot{w} N+\dot{\varepsilon} D) /(r M+w N+\varepsilon D)-\dot{p} f /(p f)
$$

and is the sum of the Solow residual,

$$
S R=\left[p \dot{F}-r(K s)^{\cdot}-w(L s)^{\cdot}\right] /(r M+w N+\varepsilon D)
$$

and the terms-of-trade effect,

$$
T T=\varepsilon \dot{\pi} g /(r M+w N+\varepsilon D)
$$

following ten Raa and Mohnen (2000). The Solow residual is a Domar weighted average of industry Solow residuals, 


$$
S R_{i}=\left[p\left(V^{T}-U\right)_{\cdot i}^{\cdot}-r K_{i}-w L_{i}\right] / p V^{\mathrm{T}}{ }_{i}
$$

where the Domar weights are

$$
p V^{\mathrm{T}}{ }_{i} S_{i} /\left(p F_{i}\right)
$$

according to Mohnen and ten Raa (2000).

\section{Rent}

In a broad sense, rent comprises all payments made to factor inputs for the provision of their services: The owner of a building collects rent from the businesses that use the space and a worker receives compensation for the labor provided. This broad concept of rent includes not only the opportunity costs of the services but also the bonuses that reflect distortions such as market power. The narrow concept of rent, however, is limited to these bonuses and, therefore, consists of the excess payments over and above the opportunity cost. It is the latter concept of rent that we use to measure departures from competition.

The first dual constraint of (2) is the value relationship between value-added and factor costs when prices are competitive. It has its counterpart for observed prices, 
which we denote by $p^{\circ}, r^{\circ}$, and $w^{\circ}$ for commodities, capital, and labor, respectively, where the superscript indicates 'observed'. Thus,

$p^{\circ}\left(V^{\mathrm{T}}-U\right)=r^{\circ} K+w^{\circ} L+\sigma^{\circ}$

Here $\sigma^{\circ}$ is defined residually and represents profits.

We define rent as the difference between observed value-added, row vector $p^{\circ}\left(V^{\mathrm{T}}\right.$ $U$ ) and competitive value-added, row vector $p\left(V^{T}-U\right)$. This expression defines rent by sector. We can impute rent (in each sector) to the factor suppliers. Substitution of (2) and (8) yields the following expression:

$$
\operatorname{Rent}=\left(r^{\circ}-r\right) K+\left(w^{\circ}-w\right) L+\left(\sigma^{\circ}+\sigma\right)
$$

In words, rent is the sum of capitalists' rent, workers' rent, and excess profits. Often capitalists' rent and excess profits are pooled, to define $K$-rent, $\left(r^{\circ}-r\right) K+\left(\sigma^{\circ}+\sigma\right)$. Similarly denoting workers' rent $\left(w^{\circ}-w\right) L$ by $L-$ rent, we obtain

$$
\text { Rent }=\text { K-rent }+ \text { L-rent }
$$

Notice that each term in (10) is a row vector of industry rents. The consolidation of profits into capital rent is apt for economies where profits accrue to shareholders, rather than workers, i.e. capitalism. All the rent terms represent excess payments, over 
and above competitive values, so that rent is a negative measure for competitiveness. This is in the spirit of Nickell (1996), who captures capital rent by putting $r=$ treasury bills rates and $\sigma=0$, and who misses labor rent. We fill the gaps by letting our general equilibrium model determine the shadow prices.

\section{Competition and performance}

The standard approach to measuring the impact of competition on performance is to regress the Solow residual (representing performance) on capital rent (representing the departure from competition):

$$
S R_{i t}=\alpha+\beta \text { K-rent }_{i t}+\varepsilon_{i t}
$$

A positive role of competition would be signaled by a negative value of $\beta$. Coefficient $\alpha$ represents technological progress due to all other reasons, including $\mathrm{R} \& \mathrm{D}$, which we will consider later. $\varepsilon_{i t}$ is an error term, i.i.d. $N\left(0, \sigma^{2}\right)$. For our panel of Canadian industries, described in the Appendix, we find $\beta=0.0005$ with $t=1.54$. Coefficient $\beta$ has the sign that agrees with the Schumpeterian perspective, but is not significant.

Now let us widen our (negative) measure of competition to all rent. Then regression equation (11) becomes 


$$
S R_{i t}=\alpha+\beta \text { Rent }_{i t}+\varepsilon_{i t}
$$

The competition coefficient flips to $\beta=-0.005$ with $t=-1.57$, assuming the neoclassical sign, but is not significant either. Still, it may that capital rent and labor rent influence performance in different ways, and, therefore, it is interesting to investigate the effects separately. Hence we regress

$$
S R_{i t}=\alpha+\beta_{K} \text { Krent }_{i t}+\beta_{L} L-\text { rent }_{i t}+\varepsilon_{i t}
$$

For this equation we find $\beta_{K}=-0.0001(t=-0.19)$ and $\beta_{L}=-0.0011(t=-2.86)$. The labor rent coefficient is negative and significant, lending support to the neoclassical viewpoint that competition is good, but limiting the mechanism to the labor market.

The preceding analysis pools all the data and it is natural to consider time and industry effects. Time effects in standard productivity analysis supposedly capture business cycle effects. In our model, however, we have already disentangled TFP into frontier productivity growth and efficiency change (see ten Raa and Mohnen 2000) and the above Solow residuals decompose the frontier productivity growth component only. Therefore we do not analyze time effects in the above equations. The relationship between competition and performance may be industry specific though. Hence we consider industry effects by making the fixed effects, $\alpha$, industry specific, so that they 
become $\alpha_{i}$. The first regression result, based on regression equation (11), with industry effects $\alpha_{i}$, yields

$$
\beta=0.0008(t=1.83)
$$

The influence of capital rent preserves the Schumpeter sign and renders it nearly significant, in fact significant at the $7 \%$ level. Repeating the widening of our (negative) measure of competition to all rent, regression equation (12), with industry effects $\alpha_{i}$, yields

$$
\beta=0.0004(t=0.85)
$$

which is still insignificant. Finally we consider capital and labor rent separately, in regression equation (13), with industry effects $\alpha_{i}$ :

$$
\beta_{K}=0.0008(t=-1.38), \beta_{L}=-0.0001(t=-0.16)
$$

As before, the sign of capital rent is Schumpeterian and the sign of labor rent is neoclassical, but the coefficients are no longer significant.

Let us summarize the evidence, however weak. On itself, capital rent exerts a positive influence on performance and it is nearly significant if industry effects are taken into account. Total rent has no significant influence. When capital and labor rents enter the 
equation separately, labor rent has a negative influence on performance and it is significant in the pooled regression.

The conflict between neoclassical and Schumpeterian economists on the role of competition has never been resolved by the evidence. When rent is disaggregated into capital rent and labor rent, some dim light is thrown on the issue. Both Schumpeter and the neoclassical economists may be right, but their mechanisms are channeled through different markets, namely the capital and labor markets, respectively. In hindsight this should not come as a surprise. Schumpeter's argument, that departures from competition may yield positive contributions to dynamic efficiency, was built on the role of $R \& D$, particularly the way it is financed. The neoclassical argument, that competition is good, has been built on the insight that it eliminates slack, particularly managerial laziness. Upon closer inspection, the arguments point at different factor markets and may both apply.

\section{R\&D}

In the empirical literature there is a consensus that $R \& D$ has a positive rate of return and hence a positive effect on TFP. To double-check the hypothesis of a Schumpeter effect from capital rent on productivity, we have regressed $R \& D$ on the input-rent components. Empirical studies on the determinants of R\&D (Cohen and Levin (1989)) find strong evidence in favor of the technological opportunity effect. The 
latter is not easy to measure and generally approximated by industry dummies. We have therefore regressed the pooled data with industry dummies. Besides technological opportunity, they also capture industry-specific innovation policies. We regress by ordinary least squares the pooled data of $R \& D$ stock on capital rent and labor rent, each lagged by one period to correct for simultaneity bias:

$$
R \& D_{i t}=\alpha+\beta_{K} K-\text { rent }_{i t}+\beta_{L} L_{-r e n t}+\varepsilon_{i t}
$$

The regression yields the following results ${ }^{1}$ :

$$
\beta_{K}=0.45(t=2.03), \beta_{L}=-0.45(t=-1.83)
$$

The regression thus confirms that capital-rents encourage R\&D as was hypothesized by Schumpeter. The existence of labor-rents is associated with lower R\&D.

\section{Conclusion}

We have investigated the influence of competition on performance. Performance was measured by Solow residuals derived from a general equilibrium model that

\footnotetext{
${ }^{1}$ Jeroen Hinloopen has noticed that the regression coefficients are exact opposites and suggested that there may be a collinearity. By definition, rent is the difference between observed and competitive value-added. The latter depends on the competitive prices. In general equilibrium analysis, including this study, the level of the competitive prices is indeterminate. It is controlled by the multiplicative factor in the objective function, see (1), and can be set such that competitive value-added matches
} 
maximizes the standard of living. The factor rewards are shadow prices, which are not necessarily equal to the observed rewards. In fact, the difference is rent, which we take as the (negative) measure of competition. Overall rent has no significant influence on performance. On itself, capital has a mild positive influence, and when taken into account separately with labor rent, the latter has a mild negative influence. Schumpeter and the neoclassical economists may both be right, but their mechanisms are channeled through different factor markets, namely the capital and labor markets, respectively. The use of rent as a source of funding for $R \& D$ applies to capital and the argument that rent yields slack pertains to labor.

If capital rent is positive for performance, but labor rent negative, the policy issue emerges how to promote technological progress without skewing the income distribution too much. An intelligent policy suggestion would be to reallocate the Schumpeterian advantages of capital rents to workers by providing them with stock options. This practice is spreading in the Western world and may indeed reconcile the opposite roles of capital and labor competition in performance.

observed value-added, whence total rent is zero. However, this collinearity is in the data, not in the dependent variables. The exact oppositeness of the regression coefficients is an artifact. 


\section{Appendix}

The constant price input-output tables obtained from Statistics Canada are expressed in 1961 prices from 1962 to 1971, in 1971 prices from 1971 to 1981, in 1981 prices from 1981 to 1986, and in 1986 prices from 1986 to 1991. All tables have been converted to 1986 prices using the chain rule. For reasons of confidentiality, the tables contain missing cells, which we have filled using the following procedure. The vertical and horizontal sums in the make and use tables are compared with the reported line and column totals, which do contain the missing values. We select the rows and columns where the two figures differ by more than 5\% from the reported totals, or where the difference exceeds $\$ 250$ million. We then fill holes or adjust cells on a case by case basis filling in priority the intersections of the selected rows and columns, using the information on the input or output structure from other years, and making sure the new computed totals do not exceed the reported ones.

There are three capital types, namely buildings, equipment, and infrastructure. ${ }^{2}$ The gross capital stock, hours worked and labor earnings are from the KLEMS database of Statistics Canada, described in Johnson (1994). In particular, corrections have been made to include in labor the earnings of the self-employed, and to separate business and non-business labor and capital. The total labor force figures are taken from

\footnotetext{
${ }^{2}$ Statistics Canada calls them "building constructions," "equipment" and "engineering constructions." Alternatively we could have modeled capital as being sector-specific, the so-called putty-clay model. We prefer the present hypothesis of mobility of each type of capital across sectors for three reasons. First, to let the economy expand, we would have needed capacity utilization rates, which are badly measured and unavailable for a number of service sectors. Second, to relieve a numerical collinearity problem, we would have to relieve the capital constraint on the non-business sector. Third, the
} 
Cansim (D767870) and converted in hours using the number of weekly hours worked in manufacturing (where it is the highest). Out of the 50 industries, neither labor nor capital stock data exist for sectors $39,40,48,49,50$, and no capital stock data for industry 46. The capital stock for industry 46 has been constructed using the capital/labor ratio of industry 47 (both industries producing predominantly the same commodity).

The international commodity prices are approximated by the U.S. prices, given that $70 \%$ of Canada's trade is with the United States. We have used the U.S. producer prices from the U.S. Bureau of Labor Statistics, Office of Employment Projection. The 169-commodity classification has been bridged to Statistics Canada's 94commodity classification. As the debt constraint in (1) is given in Canadian dollars, we convert U.S. prices to Canadian equivalents. We have used, whenever available, unit value ratios, (UVRs, which are industry specific) computed and kindly provided to us by Gjalt de Jong (1996). The UVRs are computed using Canadian quantities valued at U.S. prices. For the other commodities, we have used the purchasing power parities (PPP) computed by the OECD (which are based on final demand categories). The UVRs establish international price linkages for 1987, the PPPs for 1990 in terms of Canadian dollars per U.S. dollar. We hence need two more transformations. First, U.S. dollars are converted to Canadian dollars using the exchange rates taken from Cansim (series 0926/133400). Second, since the input-output data are in 1986 prices, we need the linkage for 1986, which is computed by using the respective countries' 
commodity deflators: the producer price index for the U.S. (see above) and the total commodity deflator from the make table (except for commodities 27, 93 and 94, for which we use the import deflator from the final demand table) for Canada. Finally, international commodity prices are divided by a Canadian final demand weighted average of international commodity prices to express them in real terms.

The following commodities are considered non-tradable: services incidental to mining, residential construction, non-residential construction, repair construction, retail margins, imputed rent from owner occupied dwellings, accommodation $\&$ food services, supplies for office, laboratories \& cafeterias, and travel, advertising \& promotion, for which no trade shows up in the input-output tables for most of the sample period.

The structure of some non-tradability constraints implies the equality of the activity levels of "construction" and final demand, "owner-occupied dwellings" and final demand, and "printing and publishing" and "travel, advertising and promotion." We have forced the activity level of industry 39 (government royalties on natural resources, which essentially pertains to oil rigging in Alberta) to follow industry 5 (crude petroleum and natural gas) to ensure there are no such royalties without oil rigging. A more detailed documentation of the data and their construction is available from the authors upon request. 


\section{References}

Aghion, P., C. Harris, P. Howitt and J. Vickers, "Competition, Imitation and Growth with Step-by-Step Innovation,” Review of Economic Studies 68, 467-92 (2001)

Aghion, P., N. Bloom, R. Blundell, R. Griffith and P. Howitt, "Competition and Innovation: An Inverted-U Relationship," UCL, mimeo (2002)

Blundell, R., R. Griffith and J. van Reenen, "Market Share, Market Value and Innovation in a Panel of British Mnaufacturing Firms," Review of Economic Studies, 66, 529-554 (1999)

Boone, J., "Intensity of Competition and the Incentive to Innovate," International Journal of Industrial Organization 19, 705-26 (2001)

Cohen, W. M. and R. C. Levin, "Empirical Studies of Innovation and Market Structure”, in Handbook of Industrial Organization, Vol. II R, Schmalensee and R.D. Willig (eds.). Elsevier Science Publishers, Amsterdam (1989)

Griffith, R., "Product Market Competition, Efficiency and Agency Costs: An Empirical Analysis,” The Institute for Fiscal Studies, WP01/12 (2001) 
Lerner, A., "The Concept of Monopoly and the Measurement of Monopoly Power," Review of Economic Studies 1, 157-175 (1934)

Mohnen, P. and Th. ten Raa, "A General Equilibrium Analysis of the Evolution of Canadian Service Productivity," Structural Change and Economic Dynamics 11, 491$506(2000)$

Nickell, S., “Competition and Corporate Performance," Journal of Political Economy $104(4), 724-746(1996)$

ten Raa, Th., and P. Mohnen, "Neoclassical Growth Accounting and Frontier Analysis: A Synthesis,” Journal of Productivity Analysis 18, 111-28 (2002) 